\title{
Örgütsel Adaletin Örgütsel Vatandaşlık Davranışına Etkisinde İş Tatmininin Aracı Rolü
}

\author{
The Mediating Role of Job Satisfaction in The Effect of Organizational Justice on The \\ Organizational Citizenship Behavior
}

\author{
Sebahattin YILDIZ1
}

\begin{abstract}
ÖZET
Araştırmanın temel amacı, Kars ilindeki hastanelerde çalışan hemşirelerin örgütsel adalet algıları, iş tatminleri ve örgütsel vatandaşlık davranışlarının düzeyini ve birbirleri ile olan ilişkilerini inceleyerek iş tatmininin bu ilişkideki aracı rolünü analiz etmektir. Ayrıca hemşirelerin cinsiyet, yaş, eğitim, nöbet tutma ve kıdem durumlarına göre bu değişkenlerin farklııı gösterip göstermediği de incelenmiştir. Araştırma açıklayıcı nitelikte tasarlanmıştır ve veri toplama yöntemi ankettir. Kolayda örnekleme yoluyla 147 örneğe ulaşılmıştır. Araştırmanın bulgularına göre, süreç adaletinin örgütle ilgili örgütsel vatandaşlık davranışı üzerindeki etkisinde iş tatminin tam aracı rolü varken, etkileşim adaletinin kişiyle ilgili örgütsel vatandaşlık davranışı ve örgütle ilgili örgütsel vatandaşlık davranışı üzerindeki etkisinde iş tatmininin tam aracı rolü vardır. Ayrıca cinsiyet, yaş, eğitim ve nöbet tutma duruma göre değişkenler anlamlı farklııı göstermemişken sadece kıdeme göre dağıtım, süreç ve etkileşim adaleti ile iş tatmini düzeyi farklılık göstermiştir. 1 yıldan daha az kıdemli olanlar diğerlerine göre daha yüksek düzeyde adalet algısı ve iş tatmini hissettiklerini belirtmişlerdir.
\end{abstract}

Anahtar Kelimeler: Örgütsel adalet, iş tatmini, örgütsel vatandaşlık davranışı, aracı rol, yapısal eşitlik modellemesi

\section{GíRiş}

Son yıllarda rekabetin en güçlü kaynağının insan olduğu ve örgüt içindeki insan davranışlarının anlaşılarak istenen doğrultuda yönlendirilmesi gerçeği oldukça kabul edilen bir olgudur. Bu bağlamda örgütsel adalet, örgütsel vatandaşlık ve iş tatmini konuları insan davranışını örgüt hedefleri doğrultusunda yönlendirmede önem arz edebilmektedir. Adalet, yazında "adillik" ve "eşitlik"terimleri ile de ifade edilen ve insan davranışlarını motive eden evrensel ve temel sosyal değerdir (Moorman, 1991:845). Örgütsel adalet kavramının çalışanlar üzerindeki etkisini inceleyen çalışmalarda, çalışanların işyerinde adaleti nasıl algıladıkları ve adaletin iş sonuçları üzerine etkisine odaklanılmaktadır (Cohen-Charash

\begin{abstract}
Main objective of the study was to examine the levels and relations of organizational justice perceptions, job satisfactions and organizational citizenship behaviors of nurses working in hospitals in the province of Kars and to analyze the mediator role of job satisfaction in this relation. Besides, the study also investigated whether these variables differed according to the gender, age, education, watch and seniority of nurses or not. The study was designed in an explanatory quality and questionnaire was used as the data collection method. 147 samples were reached by means of convenience sampling. According to findings of the study, job satisfaction had a full mediator role on the effect of process justice on organizational citizenship behavior regarding the organization and had a full mediator role on the effect of interactional justice on organizational citizenship behavior regarding the individual and organizational citizenship behavior regarding the organization. Furthermore, while the variables of gender, age, education and watch showed no significant difference, only the distribution by seniority, process and interactional justice and level of job satisfaction showed a difference. Individuals with a seniority of less than 1 year stated that they felt higher level of justice perception and job satisfaction compared to others.
\end{abstract}

Keywords: Organizational justice, job satisfaction, organization citizenship behavior, mediating role, structural equality modeling

ve Spector, 2001:279). Bu iş sonuçlarından birisi iş tatmini olgusudur ve örgütler başarıya ulaşabilmek için çalışanlarının mutluluğunu sağlama yoluna gitmektedirler.

Yine örgütlerde çalışanların örgütsel vatandaşlık davranışı sergilemeleri örgütsel adalet algıları ve iş tatminleri ile ilişkili olabilmektedir. Çizilen bu çerçevede, araştırmanın temel amacı örgütsel adalet algısının iş tatmini ve örgütsel vatandaşlık davranışına etkisini analiz etmek ve bu etkide iş tatminin aracı rolünü yapısal eşitlik modellemesi yoluyla ortaya çıkarmaktır. Ayrıca demografik özelliklere göre örgütsel adalet, örgütsel vatandaşlık davranışı ve iş tatmini değişkenlerindeki farklılıklar da ortaya çıkarıımıştır. 
$\mathrm{Bu}$ araştırmanın yapılmasındaki temel neden daha önce Kars ilindeki hemşireler üzerinde bu şekilde bir araştırmanın yapılmamış olmasıdır. Ayrıca araştırmacıları bu şekilde bir araştırma yapmaya motive eden unsurlar hemşirelerin örgütsel adalet, örgütsel vatandaşlık ve iş tatmini düzeylerinin ve bunlar arasındaki ilişkilerin belirlenmesinin temel bir katkı sağlayacak olmasıdır.

\section{KURAMSAL ÇERÇEVE}

\section{1. Örgütsel Adalet}

Örgütsel adalet kavramı Adams'ın (1965) Eşitlik Kuramına kadar uzanmaktadır ve Eşitlik Kuramından yola çıkan araştırmacılar örgüt içinde adalet konusuyla ilgilenmeye başlamışlardır. Örgütsel adalet, kazançların dağıtılması, dağıtım kararlarının alınmasında kullanılan prosedürler ve bireyler arası etkileşimle ilgili geliştirilen kurallar ve sosyal normlar olarak ifade edilebilir (Erkuş vd., 2011: 246). Örgütsel adalet, genel anlamdaki adalet algısının iş yerine yansıması yani iş yerine ilişkin adalet algısıdır. Örgütsel adalet, ekonomik değerlerin paylaşımında adil olmanın yanı sıra, yönetimin izlediği politikaların da adil olmasını ifade eder ve bireyler arasında herhangi bir ayrım gözetmeden ilişkilerin geliştirilmesine, çalışanların kişiliğine ve kültürel değerlerine saygılı davranmayı öngörmektedir (Cremer, 2005: 4). Örgütsel adalet ile ilgili yapılan sınıflandırmalarda farklılıklar görülmesine rağmen, en sık karşılaşılanı "dağıtım adaleti (distributive justice), işlemsel adalet (procedural justice) ve etkileşimsel adalet (interactional justice)" biçiminde yapılan sınıflandırma biçimidir (Olkonen ve Lipponen, 2006: 203). Dolayısıyla örgütsel adalet yazınında en yaygın kullanılan, dağıtımsal, işlemsel/ prosedürel ve etkileşimsel adalet boyutları aşağıda kısaca anlatılmıştır (Cohen-Charash ve Spector, 2001:281).

Dağıtım adaleti, kısaca örgütte çıktıların dürüstçe paylaşılmasıdır. İşgörenlerin örgüte sağladıkları katkıya karşılık olmak üzere, örgütçe yapılan paylaştırma ve sonuçların adilliği konusundaki kanaatlerine işaret etmektedir (Saunders vd., 2003: 362). "Dağıtım adaleti ilkesine göre, bireylere öyle davranılmalıdır ki bu davranış subjektif olmayan ve ahlaki temelde olmalıdır. Buna göre belli açılardan birbirine benzeyen kişilere aynı düzeyde davranılmalı, farklı olan kişilere ise, bu farklııkları dikkate alınarak farklı davranılmalıdır" (Foley vd., 2002: 473-474). Dolayısıyla dağıtım adaleti, örgüt içinde çalışanların elde ettikleri çeşitli kazanımların (ücret, ödül, terfi vb) adil olup olmadığına ilişkin algılamalarıdır (Gürbüz, 2008: 55) ve örgütsel kararların sonuçlarına gönderme yapmaktadır (Campbell ve Finch, 2004: 179).
İşlemsel veya prosedürel adalet, kısaca çıktıların paylaşılması sürecinin adil olmasıdır. "Maaş, atama olanakları, maddi imkanlar, iş koşulları ve performans değerlemesi gibi faktörlerin belirlenmesi ve hesaplanmasında kullanılan metot, süreç ve politikaların adil olma derecesidir" (Greenberg, 1990:402). Işlemsel adalet, örgüt içi kararların uygulanmasında etik, ahlak ve güveni esas almaktadır ve ödül dağıtımına ilişkin karar alma sürecindeki tarafsızlık veya objektif olmayla ilişkilidir (Chan 2000: 73). Örgütsel açıdan işlemsel adalet, kazanımları belirlemede kullanılan yöntemlerin, araçların ve süreçlerin algılanan adaletidir. Buna göre işlemsel adalet kavramı ile işgörenler örgütsel kararların adaletini tayin ederken, sadece bu kararların ne olduğu ile ilgilenmediklerini aynı zamanda bu kararları belirleyen prosedürlerle de ilgilendiklerini savunmaktadırlar (Çakmak, 2005: 31). İşlemsel adaleti uygulandığında, yönetsel kararlardan etkilenen insanlar karar verme sürecini ve sürecin tarafsız olduğunu onaylarlar. (Greenberg ve Baron, 2000: 145). İslemsel adalet boyutu çalışanların maddi beklentileri (ücret, terfi, prim, ikramiye gibi) ile sınırlı değildir. Çalışma koşullarına yönelik olarak alınan kararlarda izlenen strateji ve politikaların adil olma derecesi ile de ilişkilidir (Jahangir vd., 2006: 23). Lambert vd. (2007:645) dağıtım adaleti ile işlemsel adalet arasındaki farkı; dağıtım adaleti sonuçlarla ilgiliyken, işlemsel adalet örgütteki izlenen yol veya yöntemle ilgilidir. İşlemsel adalet daha çok örgütsel bağlılık ve örgütsel vatandaşlık davranışı gibi sonuçlarla ilişkilidir (Colquitt vd., 2001:425).

Etkileşim adaleti, kısaca organizasyonlarda bireyler arası ilişkilerin ve kişilerarası davranışların adil olmasıdır. Yöneticilerin kararlarının, işgörene saygı ve verilen kıymeti gösteren, daha açık bir ifade ile yöneticilerin işgörene davranışlarını açıklamaya çalışan bir adalet biçimini ifade etmektedir (Bies ve Moag, 1986:43). Etkileşim adaletinin, insani ve sosyal ağırlığı daha fazladır ve kişiler arası ilişkilere ve bu ilişkilerin sonuçlarına daha fazla önem vermektedir (Ramamoorthy ve Flood, 2004: 249). Etkileşimsel adalet, süreçlerin uygulanması sırasında kişiler arası davranışların algılanan adaleti olarak da tanımlanmaktadır (Cohen- Charash ve Spector, 2001:285) ve sosyal deneyimlerin sonucu ve bireyler arası ilişkilerin belirli bir kalite düzeyinde olmasına bağlı olarak gerçekleşmektedir. Etkileşimsel adalet, yöneticilerin örgütsel faaliyetlerle ilgili (işlemsel ve dağıtımsal) işlemleri uygularken çalışanların karşı karşıya kaldığı tutum ve davranışların özelliklerini ifade etmektedir (Liao ve Tai, 2006: 548). 
Örgütsel adaletin etkileyeceği değişkenler arasında lideri değerlendirme, örgütsel vatandaşıı davranışı, geri çekilme davranışı, kurallara uyma, iş gören morali, müşteri tatmini ve çatışma yer almaktadır (Cropanzano vd., 2007; Colquitt vd, 2001; Williamson ve Williams, 2011).

\section{2. İş Tatmini}

Bir kişinin iş veya ürüne karşı duygusal reaksiyonun sonucu ya da sergilediği düşünce ve hareket eğilimlerinin tümü tatmini ifade etmektedir (Verhoef, 2003: 33). İş tatmini ise, bir işgörenin işinden istediği ile elde ettiğini karşılaştırması sonucunda göstermiş olduğu duygusal tepkiyi ifade eder (Samad, 2006:113). Robbins ve Judge (2007:85), iş tatminini (doyumu veya memnuniyeti), iş görenin işine yönelik genel tutumu olarak değerlendirirken, Luthans (1995:171), iş görenin, işin kendisi için önemli olan şeyleri ne derecede karşıladığı algısının bir sonucu olduğunu ifade etmektedir. İş tatmini personelin işe karşı olan tutumu, iş çevresinin çeşitli yönleri hakkındaki olumlu değerlendirmesi ve bir bireyin işini genel olarak sevme derecesi olarak tanımlanmaktadır. İş tatmini yüksek olan bir kişi işine karşı pozitif bir tutuma sahip iken, iş tatminsizliği olan kişi negatif bir tutuma sahip olmaktadır (Robbins ve Judge, 2007:87).

İş tatmini bir işgörenin işinden hoşlanma derecesi, iş tatminsizliği ise işinden hoşlanmama derecesi olarak düşünülebilir (Yelboğa, 2012: 172). İş tatmini, "birey ile iş koşulları arasındaki uyumun bir neticesi olan memnuniyet hissidir ve bireyin işine karşı olumlu tutumu" olarak tanımlanmaktadır (Ugboro ve Obeng, 2000: 254). Organ (1988:547) iş tatmininin, duygusal ve bilişsel içeriğinin olduğunu öne sürmektedir. Duygusal içerik, kişinin mevcut duygusal halini ifade ederken; bilişsel içerik şuan ki durumun yorumlanması ve standartlarla beklentilerin karşılaştırılması anlamına gelmektedir. Netice itibariyle, iş tatmini duygusal bir tepki ve tutumsal bir özellik taşımaktadır. "İş tatmini, içsel ve dışsal iş tatmini şeklinde ayrılabilir. İçsel iş tatmini; çalışanların kendilerini etkileyen durumları belirleme konusunda inisiyatif aldığı ve hayatlarından sorumlu olarak davranışta bulunmalarını ifade ederken; dışsal iş tatmini çalışanların dış koşullar olan kısmet ve kadere bağlı olarak davranışta bulunmalarıdır" (Kutaniş ve Mesci, 2010: 531).

"iş memnuniyeti, işgörenlerin esenliğini artırır ve onların işine kenetlenmesini, verimli olmasını, hata ve israf oranının düşmesini, işten ayrılmaların azalmasını sağlamaktadır" (Querstein vd., 1992:860). Iş tatmini, kurumların hedeflerine ulaşabilmesi ve çalışanların işlerini etkin bir biçimde yapabilme- sine katkı sağlarken, iş tatminsizliği, çalışanların işgücü verimsizliği, işe devamsızlığı ve davranış bozukluklarına neden olmakta ve kurumun işleyişini olumsuz yönde etkilemektedir (Lambert vd., 2007:650). "Iş tatmini, işgörenlerin işlerine, çalışma koşullarına, meslektaşlarına yönelik duygu, düşünce ve davranışlarının bir çıktısını ifade etmektedir" (Solmuş, 2004: 186). Çalışma ortamındaki gürültü ve ışıklandırma gibi fiziksel; sorumluluk ve rol belirsizliği gibi bireysel; kişilerarası ve örgütsel faktörler, işgörenlerin iş tatminindeki iyileşmelerle ilişkili olabilmektedir (Batıgün ve Şahin, 2006: 33).

Sağlık personelinin iş tatmini hem sağlık kurumları hem de çalışanlar açısından önem taşımaktadır ve çalışanların işte kalma niyetlerini sürdürmesinin yanı sıra müşterilere daha kaliteli hizmetin sunulmasını da sağlamaktadır (Acker, 2004:70). Çalışanların yüksek performans gösterebilmeleri ve verimli bir şekilde çalışabilmeleri, onların işlerinden yeterince tatmin olmalarına bağlıdır (Toker, 2007: 92). "İş tatmini, iş koşullarının veya işten elde edilen kazançların bireysel bir değerlendirmesidir ve kişinin hem iş hem de iş şartlarıyla ilgili içsel reaksiyonlardan meydana gelmektedir" (Çekmecelioğlu, 2005:30).

\section{3. Örgütsel Vatandaşlık}

Örgütsel vatandaşık davranışı (ÖVD), biçimsel ödül sisteminde tam olarak bulunmayan fakat, bir bütün olarak örgütün işlevlerini yerine getirmesine yardımcı olan, gönüllülüğe dayalı davranışlardır (Organ, 1990:45). ÖVD ile ilgili araştırmalarda bu kavram fazladan rol (extra-role) davranışı, prososyal (prosocial) davranış, kendiliğinden (spontenaous) davranış, bağlamsal (contextual) performans ve iyi asker sendromu (good soldier syndrome) gibi kavramlarla benzer anlamda kullanılmış iken biçimsel (in-role) rol davranışı ile zıt anlamda kullanılmıştır (Moorman ve Blakely, 1995:127; Gürbüz, 2006: 50) "ÖVD, işgörenlerin resmi rol davranışlarından farklı olarak şirkete katkı sağlayan ve gönüllü olarak yaptığı davranışlardır" (Smith vd., 1983:658). "ÖVD, şirket çalışanlarının bir emire dayanmadan isteyerek yaptığı beklenen ötesi davranışlardır ve katkıya aktif katılım ile zarardan uzak durma şeklinde ikiye ayrılmaktadır" (Basım ve Şeşen, 2006: 85).

Organ (1988, 1997), ÖVD'nı diğerkâmlık/ yardımlaşma/özgecilik (altruism), nezaket (courtesy), vicdanlılık/ bilinçlilik (conscientiousness), centilmenlik/sportmenlik (sportmanship) ve sivil erdem (civic virtue) olmak üzere beş boyutta ele almıştır. Williams ve Anderson (1991: 601) tarafından yapılan çalışmada ise bu beş boyut farklı şekilde ele alınmıştır ve ÖVD, bireye yönelik spesifik davranışlar yani örgüt 
içindeki bireyleri hedef alan davranışlar (ÖVD-Kişi) ve örgütün bütününe yönelik davranışlar yani örgütün yararına olanlar (ÖVD-Örgüt) şeklinde iki kategoride incelenmiştir.

Organ (1988)'ın tanımladığı diğerkâmlık ve nezaketin Kişiye Yönelik ÖVD'ları (ÖVD-Kişi); vicdanlılık, sivil erdem ve centilmenliğin ise Örgüte Yönelik ÖVD'ları (ÖVD-Örgüt) kapsadığı şeklindedir. Bu ayrım diğer çalışmalarda da ele alınmıştır (Şeşen,2010a; Mert, 2010).

\section{Kișiye Yönelik ÖVD}

Diğerkâmlık, diğer kişilere yardım etmeye veya işle ilişkili sorunların ortaya çıkmasını önlemeye yönelik gönüllü davranışlardır. Diğerkâmlık, "bir işgörenin, işletme sorunları ve görevlerinde diğer işgörenlere yardım etme amaçlı gönüllü davranışları" olarak tanımlanmaktadır (Podsakoff ve MacKenzie, 1994: 351). Çalışma ortamında diğerkamlık boyutunu oluşturan davranışlara, işinde başarısız olan bir işgörene yardımcı olma, hastalık nedeniyle işe geç kalan arkadaşının görevini üstlenme, işe yeni başlayanlara gönüllü olarak oryantasyon konusunda yardım etme örnek olarak verilebilir (Gürbüz, 2006: 55). Başka bir ifadeyle diğerkâmlık, işletmedeki diğer çalışanlara karşılık beklemeden yardım etmeye ve problemlerin oluşmasını önlemeye yönelik istekli davranışlardır.

Nezaket, başkalarının işlerini etkileyecek hareketler yapmadan veya kararlar almadan önce diğerlerini bilgilendirmeye dayanan davranışlardır. Nezaket boyutu, "işletmede etkileşim içinde olmaları gereken işgörenlerin gerektiğinde birbirlerini uyarma ve hatırlatma davranışlarında bulunmalarıdır" (Organ, 1988: 47). Herhangi bir problem veya sorun ortaya çıkmadan örgüt üyelerini uyarmak, verilecek bir karardan etkilenebilecek kişilerin önceden fikirlerini almak, örgüt içinde önemli konularla ilgili diğer çalışanlara bilgi sağlamak örnek olarak verilebilir. Yani, nezaket boyutu, "işgörenlerden kaynaklanan problemleri onların haklarını ihlal etmeden önlemeye yönelik gönüllü davranışı" ifade eder (Arslantaş ve Pekdemir, 2007: 265).

\section{Örgüte Yönelik ÖVD}

Vicdanlılık, "işgörenlerin onlardan beklenen temel rol davranışından daha fazla bir davranışı gönüllü sergilemeleri" (Organ, 1988:550) ya da örgüt üyelerinin asgari rol gereklerinin üzerinde gönüllü olarak sergiledikleri davranışlardır. Kişinin fazla mesai ücreti almasa da işini bitirmek için mesaiye kalması, olumsuz hava koşullarında ve hastalık durumunda işine gelmesi, molaları gereksiz uzatmaması örnek olarak verilebilir. Yani vicdan sahibi olma boyutu, "çalışanların fazla çalışarak, ilkelere karşı gelmeden asgari rol davranışının ötesine geçerek gönüllü davranış göstermelerini" ifade eder (Farh vd., 2004: 241).

Sivil erdem, "şirkete karşı tamamıyla bağlı yada üst düzeyde ilgili olmayı" ifade etmektedir (George ve Jones, 1997:154). Örgütü etkileyen olaylara karşı çalışanların kendilerini sorumlu kılmaları, toplantılara gönüllü bir şekilde katılmaları ve örgütün politik hayatına aktif olarak katılmalarını ifade etmektedir (Podsakoff ve MacKenzie, 1994: 351). Bir kişinin örgütün toplantılarına düzenli olarak katılması, örgütün amaçları doğrultusunda alınan kararları desteklemesi ve örgütteki yeni gelişmelere ayak uydurması örnek olarak gösterilebilir.

Centilmenlik, işe ilişkin kaçınılmaz sorunları veya zorlukları şikayet etmeden kabul etme istekliliği olarak tanımlanabilir (Basım ve Şeşen, 2006: 87-88). Centilmenlik boyutu, çalışanların çalışma ortamında gerginliğe ve çatışmaya sebep olabilecek olumsuz davranışlardan kaçınmaları ve önemsiz sorunlardan dolayı şikayette bulunmamayı öngören davranışlardır (Organ, 1990: 96). Bir kişinin çalışma arkadaşlarına saygılı olması, sorunları çok büyütmemesi ve işlerin olumlu yönlerini görmesi örnek olarak verilebilir. Yani centilmenlik boyutu, işin sorunlarına ve zorluklarına şikayet edilmeden müsamaha gösterilmesini ve gerginlik yaratabilecek olumsuz davranışlardan kaçınılmasını ifade eder (Arslantaş ve Pekdemir, 2007: 265).

\subsection{Araştırma Değişkenleri Arasındaki İlişkiler}

Araştırma değişkenleri arasındaki ilişkiler Adams'ın (1965) Eşitlik Kuramı'na (Equity Theory) dayanmaktadır. Eşitlik Kuramı́ndan yola çıkarak, çalışanın örgütsel adalet algısı yükseldiğinde iş tatmininin artması ve örgütsel vatandaşlık davranışı sergilemesi beklenmektedir.

\subsection{1. Örgütsel Adalet ve İş Tatmini İlişkisi}

Yelboğa (2012), örgütsel adalet algısının iş doyumunu belirleyen etmenlerden biri olduğunu ve dağıtım adaleti ile kişilerarası adalet algısının iş doyumu üzerinde etkili olmasına karşın, işlemsel adalet ile bilgisel adalet algılarının iş doyumu üzerinde etkisinin olmadığını tespit etmiştir. Çetin vd. (2011), işlemsel adalet, dağıtım adaleti, etkileşim adaleti ve genel adalet uygulamalarının artmasıyla, kişilerin işlerine yönelik iç ve dış tatminleri yanında genel tatminlerinin de arttığını tespit etmişlerdir. Erkuş vd. (2011), dağıtım adaleti ve etkileşim adaletinin dışsal iş tatmini, etkileşim adaletinin ise içsel iş tatmini üzerinde pozitif yönde etkilerini tespit etmiştir. İşcan ve Sayın (2010), örgütsel adalet, iş tatmini ve güven 
arasında pozitif bir ilişki olduğunu ortaya çıkarmıştır.

Şeşen (2010b), adalet algısı ve tükenmişlik davranışı arasında anlamlı bir ilişki olduğunu ve bu ilişkide iş tatminin aracılık rolü oynadığını göstermiştir. Yine dağıtım, prosedür ve etkileşim adaleti ile iş tatmini arasında pozitif yönde ilişkiler ortaya çıkmıştır. Özer ve Günlük (2010)'a göre prosedürel adalet algısı arttıkça, iş memnuniyetleri artmakta, fakat işten ayrılma eğilimleri azalmaktadır. Kutaniş ve Mesci (2010), örgütsel adalet boyutlarından dağıtımsal ve işlemsel adalet boyutlarının, içsel iş tatmini ve dışsal iş tatmini üzerinde önemli ölçüde etkili olduğunu tespit etmiştir. Yürür (2008), prosedür ve etkileşim adaleti algısının iş tatminini etkilediğini tespit etmiştir.

Dinç ve Ceylan (2008), örgütsel adaletin alt boyutlarından dağıtımsal adalet ile iş memnuniyetinin alt boyutlarından yapılan işten memnuniyet arasında pozitif yönde anlamlı bir ilişki gözlemiştir. Yıldırım (2007), iş doyumu ile dağıtım, işlem ve etkileşim adaleti arasında pozitif ilişkiler gözlemiştir. Cropanzano vd. (2002)'e göre kişilerarası etkileşim adaleti algısı iş tatmini düzeyinin belirlenmesinde temel bir ölçüt oluşturmaktadır. Colquitt vd. (2001) bireylerin iş tatminlerinin örgütsel adaletin tüm boyutlarından etkilendiğini ortaya koymuştur. Cohen-Charash ve Spector (2001:287)'e göre, yönetimle ilgili tatmin dağıtım adaleti ve işlemsel adaletle, ücret tatmini ise daha çok dağıtım adaleti ve işlemsel adaletle ilişkili çıkmıştır. Martin ve Bennett (1996) dağıtım ve prosedür adaletinin iş tatmini ile pozitif yönde ilişkisini bulmuşlardır.

Yoon (1996) işlem adaletinin dağıtım adaletine göre iş tatmini daha çok artırdığını belirtmiştir. Lowe ve Vodanovich (1995), işlem adaletinin iş tatminini pozitif ve anlamlı olarak etkilediğini belirlemişlerdir. McFarlin ve Sweeney (1992), prosedür ve dağıtım adaleti algısının iş tatmini ile pozitif yönde ilişkisi oluğunu ve dağıtım adaletinin, iş tatmini üzerindeki etkisinin prosedür adaletinden daha fazla olduğunu vurgulamışlardır. Alexander ve Ruderman (1987), işlem adaleti ile iş tatmini arasında pozitif yönde ilişki gözlemiştir.

\subsection{2. Örgütsel Adalet ve Örgütsel Vatandaşlık Davranışı İlişkisi}

İnce ve Gül (2011), prosedürel adalet ile örgütsel gelişime katkı ve işe yönelik özen arasında olumlu ilişki rapor etmiştir. Polat ve Celep (2008), örgütsel adalet algısı ile örgütsel vatandaşlık davranışı arasında olumlu orta düzeyde bir ilişki olduğunu bulmuştur.

Arslantaş ve Pekdemir (2007), örgütsel adalet ve boyutlarının örgütsel vatandaşlık boyutları ile pozitif yönde ilişkili olduğunu gözlemiştir. Konovsky ve
Organ, (1996) örgütsel vatandaşlık davranışının adalet algısından etkilendiği belirtmiştir. Tansky (1993), özgecilik ve vicdan sahibi olma ile örgütsel adalet arasında anlamlı ilişkiler bulmuştur. Organ (1990), örgüte ilişkin adalet algılarının işgörenlerin örgütsel vatandaşlık davranışları gösterme eğilimini etkilediğini belirtmiştir.

\subsection{3. İş Tatmini ve Örgütsel Vatandaşlık Davranışı İlişkisi}

Li vd. (2010), iş tatmininin örgütsel vatandaşlık davranışının önemli bir yordayıcısı olduğunu ortaya koymuştur. Sert (2010), iş tatmininin alt boyutlarından işin kendisinden duyulan tatminin bireye ve örgüte yönelik ÖVD'nı olumlu yönde, ücretten duyulan tatminin ise bu davranışları olumsuz yönde etkilediğini bulmuştur.

Demirel ve Özçınar (2009), örgütsel vatandaşlık düzeyi arttıkça çalışanların iş tatmini düzeyinin arttığını ifade etmiştir. Podsakoff vd. (2000), örgütsel vatandaşlık davranışını etkileyen örgütsel faktörlerden birisinin iş tatmini olduğunu belirtmiştir.

\subsection{4. Örgütsel Adalet, İş Tatmini ve Örgütsel Vatandaşlık Davranışı iliş̧kileri}

Şeşen (2010a), ÖVD-Kişi (diğergamlık ve nezaket) üzerinde örgütsel adalet boyutlarının anlamlı etkisinin olmadığını, ÖVD-Örgüt (vicdan, sivil erdem ve centilmenlik) üzerine ise süreç adaletinin pozitif etkisinin olduğunu gözlemiştir. Ayrıca ÖVD-Kişi üzerinde iş tatminin etkisinin olmadığını, ÖVD-Örgüt üzerinde ise iş tatmininin pozitif etkisinin olduğunu bulmuştur.

Gürbüz (2008), çalışanların iş tatminlerinin ve örgütsel adalet algılarının, sergileyecekleri örgütsel vatandaşlık davranışlarını anlamlı düzeyde etkilediğini ortaya çıkarmıştır. Ayrıca örgütsel adalet algısının örgütsel vatandaşlık davranışına etkisinde iş tatmininin tam aracılık ettiğini tespit etmiştir.

\section{ARAŞTIRMA}

\subsection{Araştırmanın Amacı ve Kapsamı}

Araştırmanın temel amacl, Kars ilindeki hastanelerde çalışan hemşirelerin örgütsel adalet algıları, iş tatminleri ve örgütsel vatandaşlık davranışlarının düzeyini ve birbirleri ile olan ilişkilerini inceleyerek iş tatmininin bu ilişkideki aracı rolünü analiz etmektir. Ayrıca hemşirelerin cinsiyet, yaş, eğitim, nöbet tutma ve kıdem durumlarına göre bu değişkenlerin farklıık gösterip göstermediğini incelemek araştırmanın diğer bir amacıdır. Araştırmanın kapsamını Kars ilindeki hastanelerde çalışan hemşireler oluşturmaktadır. 


\subsection{Araştırmanın Yöntemi}

Araştırma neden sonuç ilişkisine dayalı şekilde (açıklayıcı) tasarlanmıştır. Araştırmada veri toplama yöntemi ankettir. Örnekleme yöntemi ise kolayda örneklemedir ve evreni temsil edecek düzeyde 147 örneğe ulaşılmıştır (Saruhan ve Özdemirci, 2011, 143). Araştırma evreni 427 kişiden oluşmaktadır.

Bu araştırmada kullanılan ölçekler ve ölçekler hakkındaki bilgiler şu şekildedir: Örgütsel Adalet Algısı Ölçeği, İşbaşı (2001) tarafından uyarlanmış ve 27 maddeden oluşmaktadır. Ölçek, dağıtım adaleti (7 madde), süreç adaleti (7 madde) ve etkileşim adaleti (13 madde) alt boyutlarından oluşmaktadır. Iş̧ Tatmini Ölçeği, çalışanların genel iş tatminini ölçmek üzere Basım ve Şeşen (2009)'in, Hackman ve Oldhamn (1975)'ın İş Özellikleri Anketi'nden uyarladıkları beş maddeli ve tek boyutlu ölçektir. Örgütsel Vatandaşlık Davranışı Ölçeği ise, Basım ve Şeşen (2006) tarafından uyarlanan ve diğerkamlık (5 madde), vicdanlılık (3 madde), nezaket (3 madde), centilmenlik (4 madde) ve sivil erdem ( 4 madde) boyutlarını içeren 19 maddeli bir ölçektir. Tüm sorular 5'li Likert ölçekle ölçülmüştür.

\subsection{Araştırmanın Modeli ve Hipotezleri}

Yukarıdaki literatür bilgileri ışı̆̆ında araştırmanın modeli ve temel hipotezleri aşağıda belirtildiği şekildedir.

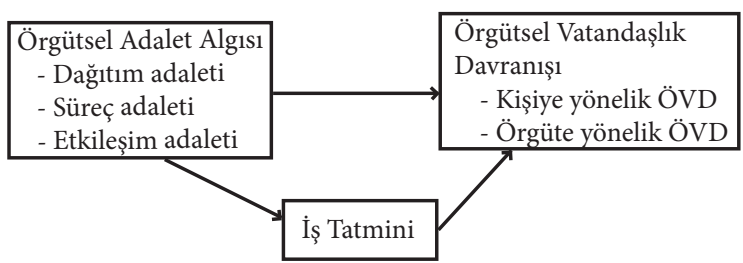

Şekil 1: Araştırmanın Modeli

$\mathrm{H}_{1}$ : Örgütsel adalet algısı boyutları örgütsel vatandaşlık davranışı boyutlarını olumlu yönde etkilemektedir.

$\mathrm{H}_{1: 1}$ :Dağıtım adaleti kişiye yönelik ÖVD'nı olumlu yönde etkilemektedir.

$\mathrm{H}_{12}$ :Dağıtım adaleti örgüte yönelik ÖVD'nı olumlu yönde etkilemektedir.

$\mathrm{H}_{1.3}$ :Süreç adaleti kişiye yönelik ÖVD'nı olumlu yönde etkilemektedir.

$\mathrm{H}_{1.4}$ :Süreç adaleti örgüte yönelik ÖVD'nı olumlu yönde etkilemektedir.

$\mathrm{H}_{1.5}$ :Etkileşim adaleti kişiye yönelik ÖVD'nı olumlu yönde etkilemektedir.

$\mathrm{H}_{1.6}$ :Etkileşim adaleti örgüte yönelik ÖVD'nı olumlu yönde etkilemektedir.

$\mathrm{H}_{2}$ : Örgütsel adalet algısı boyutları iş tatminini olumlu yönde etkilemektedir.
$\mathrm{H}_{2.1}:$ Dağıtım adaleti iş tatminini olumlu yönde etkilemektedir.

$\mathrm{H}_{22}$ :Süreç adaleti iş tatminini olumlu yönde etkilemektedir.

$\mathrm{H}_{2.3}$ :Etkileşim adaleti iş tatminini olumlu yönde etkilemektedir.

$\mathrm{H}_{3}$ : İş tatmini örgütsel vatandaşlık davranışı boyutlarını olumlu yönde etkilemektedir.

$\mathrm{H}_{3.1}$ : Iş̧ tatmini kişiye yönelik ÖVD'nı olumlu yönde etkilemektedir.

$\mathrm{H}_{3,2}$ : Iş̧ tatmini örgüte yönelik ÖVD'nı olumlu yönde etkilemektedir.

$\mathrm{H}_{4}$ : Örgütsel adaletin ÖVD'na etkisinde iş tatmininin Aracı rolü vardır.

$\mathrm{H}_{4.1}:$ Dağıtım adaletinin kişiye yönelik ÖVD'na etkisinde iş tatmininin Aracı rolü vardır.

$\mathrm{H}_{4.2}$ :Dağıtım adaletinin örgüte yönelik ÖVD'na etkisinde iş tatmininin Aracı rolü vardır.

$\mathrm{H}_{43}$ :Süreç adaletinin kişiye yönelik ÖVD'na etkisinde iş tatmininin Aracı rolü vardır.

$\mathrm{H}_{4.4}$ :Süreç adaletinin örgüte yönelik ÖVD'na etkisinde iş tatmininin Aracı rolü vardır.

$\mathrm{H}_{45}$ : Etkileşim adaletin kişiye yönelik ÖVD'na etkisinde iş tatmininin Aracı rolü vardır.

$\mathrm{H}_{4.6}$ :Etkileşim adaletin örgüte yönelik ÖVD'na etkisinde iş tatmininin Aracı rolü vardır.

\subsection{Aracılık Etkisi}

Aracılık etkisini analiz etmek için Baron ve Kenny (1986)' nin yöntemi izlenmiştir. Baron ve Kenny (1986)'nin aracılık etkisi koşullarının sağlanması 4 aşamadan oluşmaktadır:

Birinci koşulda, yordayıcı değişkenin (örgütsel adalet algısı), yordanan değişken (örgütsel vatandalık davranışı) üzerinde anlamlı etkisi olmalıdır. Ancak bu eşitlik test edilirken, eğer söz konusu ilişkiyi karıştırdığı önceden bilinen ya da tahmin edilen bir değişken varsa, bu değişkenin etkisinin kontrol altına alınması gerekmektedir.

İkinci koşulda, yordayıcı değişkenin (örgütsel adalet algısı) aracı değişken (iş tatmini) üzerinde anlamlı etkisi olmalıdır.

Üçüncü koşulda, aracı değişkeninin (iş tatmini) yordanan değişken (örgütsel vatandaşlık davranışı) üzerinde anlamlı etkisi olmalıdır.

Dördüncü koşulda hem yordayıcı (örgütsel adalet algısı) hem de aracı (iş tatmini) değişkenin birer bağımsız değişken olarak yordanan değişken (örgütsel vatandaşlık davranışı) üzerindeki etkileri hesaplanır. Bu durumda yordayıcı değişkenin yordanan değişken üzerindeki etkisinin anlamsızlaşması (Tam aracı) veya azalması (Kısmı aracı) durumunda aracılık etkisinden bahsedilir. 


\subsection{Geçerlilik ve Güvenilirlik Analizleri}

Kullanılan ölçeklerin geçerliliğini test etmek üzere, AMOS 17.0 programı ile doğrulayıcı faktör analizi yapılmıştır. Bu çerçevede örgütsel adalet ölçeği için üç faktörlü, iş tatmini için tek faktörlü, örgütsel vatandaşlık davranışı ölçeği için ise beş, iki ve tek faktörlü üç ayrı model test edilmiştir. Beş faktörlü model, diğerkamlık, vicdanlılık, nezaket, centilmenlik ve sivil erdem boyutlarını içermektedir. İki faktörlü model, diğerkamlık ve nezaketin birleşmesiyle kişiye yönelik örgütsel vatandaşlık davranışı (ÖVD_Kişi) ve vicdan, sivil erdem ve centilmenlik boyutlarının birleşmesiyle örgüte yönelik örgütsel vatandaşlık davranışını (ÖVD_Örgüt) içermektedir. Tek faktörlü model, tüm boyutların birleşimiyle tek bir genel örgütsel vatandaşlık davranışının geçerli olabildiğini göstermektedir. Bu nedenle ÖVD ölçeğinin geçerliliği üç farklı modelin testiyle araştırılmış ve en iyi uyumu veren model araştırmada kullanıımıştır.

Doğrulayıcı faktör analizi bulguları, Tablo 1'de gözüktüğü gibi, örgütsel adalet ölçeğinde üç boyutlu $\left[X^{2} / s d=2,43 ; p<.01 ; \mathrm{GFI}\right.$ (goodness of fit index)=.90; CFI (comparative fit index)=.89; IFI (incremental fit index)=.87; RMSEA (root mean square error of approximation) $=.08]$, iş tatmininde tek faktörlü $\left[\mathrm{X}^{2} / \mathrm{sd}=1,88\right.$; $\mathrm{p}<.01 ; \mathrm{GFI}=.91 ; \mathrm{CFI}=.91 ; \mathrm{IFI}=.89$; $\mathrm{RMSEA}=.08]$ ve örgütsel vatandaşlık davranışında ise kişiye yönelik ÖVD ve örgüte yönelik ÖVD olmak üzere iki faktörlü $\left[x^{2} /\right.$ $\mathrm{sd}=3,92 ; \mathrm{p}<.01 ; \mathrm{GFI}=.88 ; \mathrm{CFI}=.89 ; \mathrm{IFI}=.88 ; \mathrm{RMSEA}=.10]$ modellerin en iyi uyumu verdiği ortaya çıkmıştır.

Tablo 1: Ölçeklerin Doğrulayıcı Faktör Analizi Sonuçları

\begin{tabular}{|l|c|c|c|c|c|}
\hline \multicolumn{1}{|c|}{ Ölçek / Model } & $\mathrm{X}^{2} / \mathrm{sd}$ & $\mathrm{GFI}$ & $\mathrm{CFI}$ & $\mathrm{IFI}$ & RMSEA \\
\hline $\begin{array}{l}\text { Örgütsel Adalet (3 } \\
\text { boyutlu) }\end{array}$ & 2,43 & 0,90 & 0,89 & 0,87 & 0,08 \\
\hline $\begin{array}{l}\text { İş Tatmini (Tek } \\
\text { boyutlu) }\end{array}$ & 1,88 & 0,91 & 0,91 & 0,89 & 0,08 \\
\hline $\begin{array}{l}\text { Örgütsel Vatandaşlık } \\
\text { (2 boyutlu) }\end{array}$ & 3,92 & 0,88 & 0,89 & 0,88 & 0,10 \\
\hline
\end{tabular}

(Not: $\left.{ }^{*} \mathrm{p}<.01\right)$
Güvenilirlik analizleri için ölçeklerin iç tutarlıı̆ğını belirlemekte kullanılan Cronbach's Alpha katsayısına bakılmıştır ve Tablo 3'de görüldüğü gibi ölçeklerin güvenilirliklerinin sosyal bilimlerde istenen seviyelerde (yani 0,70 ve üzeri) olduğu ortaya çıkmıştır (Nunnally, 1978). Dolayısıyla ölçeklerin bu örneklem için geçerli ve güvenilir olduğu söylenebilir.

\section{BULGULAR}

\subsection{Demografik Özellikler}

Tablo 2'de gösterildiği gibi katılımcıların \%83,7'si kadın, \%16,3'ü erkek; \%57,1'i 21-30 yaş arasında, \%30,6'sı 31-40 yaş arasında, \%7,5'i 41 ve üzeri yaşta, \%4,8'i 20 ve altı yaşta; \%42,2'si yüksekokul, \%35,4'ü üniversite, $\% 22,4$ 'ü lise mezunu; \%32'si, 1-5 yıl arası, 29,9'u 11 yıl ve üzeri, \%19'u 6-10 yıl, \%19'u 1 yıldan daha az kıdemde; $\% 84,4$ 'ü nöbet tutuyorken $\% 15,6$ 'sı nöbet tutmamaktadır.

Tablo 2: Demografik Özellikler

\begin{tabular}{|c|c|c|c|}
\hline \multicolumn{2}{|c|}{ Değişkenler } & $N=147$ & $\%$ \\
\hline \multirow{2}{*}{ Cinsiyet } & Kadın & 123 & 83,7 \\
\hline & Erkek & 24 & 16,3 \\
\hline \multirow{4}{*}{ Yaş } & 20 ve altı & 7 & 4,8 \\
\hline & $21-30$ & 84 & 57,1 \\
\hline & $31-40$ & 45 & 30,6 \\
\hline & 41 ve üzeri & 11 & 7,5 \\
\hline \multirow{3}{*}{ Eğitim } & Lise & 33 & 22,4 \\
\hline & Yüksekokul & 62 & 42,2 \\
\hline & Üniversite & 52 & 35,4 \\
\hline \multirow{4}{*}{ Kıdem } & 1 yıldan az & 28 & 19,0 \\
\hline & $1-5$ yıl & 47 & 32,0 \\
\hline & 6-10 yıl & 28 & 19,0 \\
\hline & 11 yıl ve üzeri & 44 & 29,9 \\
\hline \multirow{2}{*}{ Nöbet tutma durumu } & Evet & 124 & 84,4 \\
\hline & Hayır & 23 & 15,6 \\
\hline
\end{tabular}

\subsection{Korelasyon Analizleri}

Tablo 3 incelendiğinde ortalama skorlara göre dağıtım adaleti algısının süreç ve etkileşim adaletine göre daha düşük düzeyde olduğu gözlenmiştir. Yine dağıtım, süreç ve etkileşim adaleti arasında 0,01 anlamlılık seviyesinde pozitif yönde orta düzeyde anlamlı ilişkiler ortaya çıkmışıı.

Tablo 3: Değişkenlere Ait Ortalamalar, Standart Sapmalar, Korelâsyonlar ve Güvenilirlik

\begin{tabular}{|c|c|c|c|c|c|c|c|c|}
\hline Faktör & Ort. & SS & 1 & 2 & 3 & 4 & 5 & 6 \\
\hline 1. Dağıtım adaleti & 1,95 & 0,67 & $(.72)^{\mathrm{a}}$ & & & & & \\
\hline 2. Süreç adaleti & 2,27 & 0,78 &, $52^{* *}$ & $(.85)^{\mathrm{a}}$ & & & & \\
\hline 3 3.Etkileşim adaleti & 2,27 & 0,84 &, $55^{* *}$ &, $58^{* *}$ & $(.92)^{\mathrm{a}}$ & & & \\
\hline 4. İş tatmini & 2,65 & 1,18 &, $41^{* *}$ &, $40 * *$ & $40^{* *}$ & $(.91)^{\mathrm{a}}$ & & \\
\hline 5. ÖVD-kişi & 4,14 & ,720. & 04 & 06 & 11 & , 16 & $(.85)^{\mathrm{a}}$ & \\
\hline 6. ÖVD-örgüt & 3,32 & 0,76 & $23^{* *}$ & $26^{* *}$ & $27^{* *}$ & $40 * *$ &, $58^{* *}$ & $(.84)^{\mathrm{a}}$ \\
\hline
\end{tabular}

( Not: a. Cronbach alpha güvenirlik katsayıları; ${ }^{*} p<.05 .{ }^{* *} \mathrm{p}<.01$ ) 
Ayrıca örgütsel adaletin üç boyutunun iş tatmini ile pozitif yönde orta düzeyde ilişkileri vardır. Yine kişiye yönelik ÖVD ile örgüte yönelik ÖVD arasında orta düzeyde pozitif yönde anlamlı ilişki gözlenmiştir. Kişiye yönelik ÖVD'nın örgütsel adalet boyutları ve iş tatmini ile anlamlı ilişkisi yokken, örgüte yönelik ÖVD'nın ise örgütsel adalet boyutları ve iş tatmini ile pozitif yönde anlamlı ilişkileri vardır.

\subsection{Yapısal Eşitlik Modellemesi ile Aracılık Testi}

Örgütsel adaletin örgütsel vatandaşlık davranışına etkisinde iş tatmininin aracılık rolü olup olmadığı iki ayrı yol analizi ile araştırımıştır. Kurulan yapısal yol analizi modelleri AMOS 17.0 yazılımı kullanılarak test edilmiştir. Meydan ve Şeşen (2011)'in ifade ettiği üzere, aracılık testlerinde yapısal eşitlik modeli kullanılması doğrusal regresyon analizine göre daha güvenilir sonuçlar vermektedir. Bu nedenle, bu araştırmada da iki ayrı yol analizi modeli kurulmuştur.

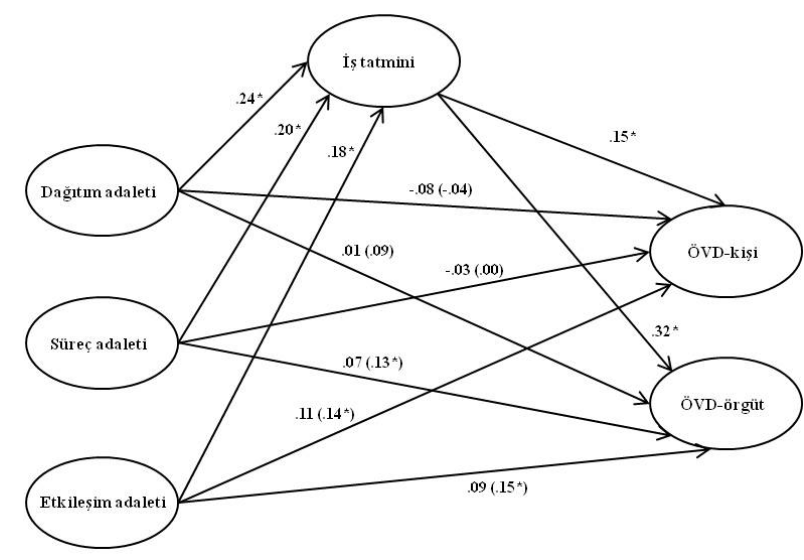

Şekil 2: Yapısal Eşitlik Modellemesi İle Aracılık Testleri

Aracılık etkisini değerlendirmek üzere yukarıda izah edilen Baron ve Kenny (1986)'nin yöntemi esas alınmıştır. Model testleri sonucunda elde edilen regresyon katsayıları Şekil-2'de verilmiştir. Buna göre birinci modelde, dağıtım adaleti boyutlarının ÖVD boyutları üzerindeki etkileri test edilmiştir. Elde edilen regresyon katsayıları her bir yol için parantez içerisinde verilmiştir. Birinci model incelendiğinde dağıtım adaletinin ÖVD boyutları üzerinde anlamlı etkisinin olmadığı (H1.1. ve H1.2. RED); süreç adaletinin sadece ÖVD-örgüt üzerinde anlamlı etkisi (H1.3. RED, $H 1$.4. KABUL) olduğu (standardize beta $=, 13 ; p<.001$ ); etkileşim adaletinin ise hem ÖVD-kişi (standardize beta $=14 ; p<.001$ ) hem de ÖVD-örgüt (standardize beta $=, 15 ; p<.001)$ üzerinde anlamlı etkisinin olduğu görülmektedir (H1.5. ve H1.6. KABUL). Birinci model kabul edilebilir uyum değerleri vermiştir $\left[\mathrm{X}^{2} / \mathrm{sd}=4,81\right.$; $\mathrm{p}<.01 ; \mathrm{GFI}=.86 ; \mathrm{CFI}=.85 ; \mathrm{IFI}=.85 ; \mathrm{RMSEA}=.12] . \mathrm{Bu}$ durumda, Baron ve Kenny (1986) yöntemi takip edildiğinde, bir sonraki modelde süreç adaleti ÖVDörgüt ilişkisi ve etkileşim adaletinin her iki ÖVD boyutu ile ilişkisi dikkate alınacaktır.

İkinci modelde iş tatmini aracı değişken olarak modele dâhil edilmiştir. Model incelendiğinde, her üç adalet algısı boyutunun iş tatmini üzerinde anlamlı etkisi olduğu görülmektedir (H2.1., H2.2. ve H.2.3. KA$B U L)$ ve dağıtım adaletinin iş tatmini üzerindeki etkisi diğerlerinden daha yüksek düzeydedir. Ayrıca iş tatmininin ÖVD-kişi (standardize beta $=, 15 ; p<.001$ ) ve ÖVD-örgüt (standardize beta=,32; $p<.001$ ) üzerinde de anlamlı etkisinin olduğu anlaşılmaktadır (H3.1. ve H.3.2. KABUL). Bu durumda Baron ve Kenny'nin 2 ve 3 'üncü şartları da sağlanmış olmaktadır. İş tatmini modele dâhil edildiğinde ise, hem süreç adaletinin ÖVD-örgüt (standardize beta=,07; p>.05), hem de etkileşim adaletinin ÖVD-kişi (standardize beta $=, 11$; $p>.05$ ) ve ÖVD-örgüt (standardize beta=,09; $p>.05$ ) üzerindeki etkileri anlamsızlaşmaktadır. Dolayısıyla, Baron ve Kenny'nin 4'üncü şartı da gerçekleşmiştir. Bu nedenle, süreç adaletinin ÖVD-örgüt üzerindeki etkisinde; etkileşim adaletinin ise ÖVD-kişi ve ÖVDörgüt üzerindeki etkisinde iş tatmini Tam aracı rol oynamaktadır (H4.1., H4.2. ve H4.3. RED; H4.4., H4.5. ve H4.6. KABUL). İkinci modelin indeks değerleri kabul edilebilir sınırlar içerisindedir $\left[\mathrm{X}^{2} / \mathrm{sd}=4,22 ; \mathrm{p}<.01\right.$; $\mathrm{GFI}=.87 ; \mathrm{CFI}=.88 ; \mathrm{IFI}=.86 ; \mathrm{RMSEA}=.11]$.

\subsection{Farklılık Analizleri}

Yapılan farklılık testleri (t testi ve ANOVA) sonucunda, cinsiyet, yaş, nöbet tutma ve eğitim durumu değişkenlerine göre örgütsel adalet boyutları, iş tatmini ve örgütsel vatandaşlık boyutları anlamlı farklılık göstermemiştir ( $p>0,05)$. Sadece kıdeme göre ise dağıtım, süreç ve etkileşim adaleti ile iş tatmini düzeyi farklılık göstermiştir $(p<0,05) .1$ yıldan daha az kıdemli olanların diğerlerine göre daha yüksek düzeyde adalet algısı ve iş tatmini hissettikleri ortaya çıkmıştır.

\section{SONUÇ, TARTIŞMA VE ÖNERILER}

Bu araştırma, Kars ilindeki hastanelerde çalışan hemşirelerin örgütsel adalet algıları, iş tatminleri ve örgütsel vatandaşlık davranışlarının düzeyini ve birbirleri ile olan ilişkileri inceleyerek iş tatmininin bu ilişkideki aracı rolünü analiz etmeyi amaçlamıştır. Diğergamlık ve nezaketten oluşan ÖVD-Kişi düzeyi en yüksek ortalama skoru elde etmişken, örgütsel adalet boyutlarından dağıtım adaleti ise en düşük ortalama skora sahip olarak ortaya çıkmışır.

Araştırma sonucunda, dağıtım, süreç ve etkileşim adaleti arasında; örgütsel adaletin üç boyutu ile iş 
tatmini arasında; kişiye yönelik ÖVD (diğerkamlık ve nezaket) ile örgüte yönelik ÖVD (vicdan, sivil erdem ve centilmenlik) arasında; örgüte yönelik ÖVD ile örgütsel adalet boyutları ve iş tatmini arasında pozitif yönde ilişkiler ortaya çıkmıştır. Sadece kişiye yönelik ÖVD (diğergamlık ve nezaket) ile örgütsel adalet algısı boyutları ve iş tatmini arasında anlamlı ilişkiler gözlenmemiştir. Bu bulgu Şeşen (2010a: 210)'in çalışmasında da ortaya çıkmıştır.

Ayrıca, dağıtım adaletinin hem ÖVD-Kişi hem de ÖVD-Örgüt boyutları üzerinde anlamlı etkisinin olmadığı; süreç adaletinin sadece ÖVD-örgüt üzerinde anlamlı etkisi olduğu; etkileşim adaletinin ise hem ÖVD-kişi hem de ÖVD-örgüt üzerinde anlamlı etkisinin olduğu gözlenmişsir.

Ayrıca örgütsel adalet algısı boyutları iş tatmini olumlu yönde etkilemektedir. Bu bulgu, Çetin vd (2011), Erkuş vd (2011), Kutanis ve Mesci (2010), Podsakoff vd, (2000) ve Li vd (2010)'nin çalışmalarında da gözlenmiştir.

Yine iş tatmininin örgütsel vatandaşlık boyutları üzerinde olumlu yönde etkisi olmuştur. Bu bulgu Colquitt vd (2001), Yürür, (2008), Demirel ve Özçınar (2009), Li vd (2010), Erkuş vd (2011) ve Çetin vd, (2011)'in çalışmalarında da gözlenmiştir.

Yine, süreç adaletinin örgütle ilgili örgütsel vatandaşlık davranışına etkisinde iş tatminin tam aracı rolünün olduğu gözlenmişken, etkileşim adaletinin kişiyle ilgili örgütsel vatandaşlık davranışına ve örgütle ilgili örgütsel vatandaşlık davranışına etkisinde iş tatmini tam aracı rol oynadığı ortaya çıkmıştır. Bu bulgu kısmen Gürbüz (2008)'in çalışmasında da ortaya çıkmıştır.

Bulgular yorumlandığında, dağıtım adaletinin sağlanması, çalışanların ÖVD sergilemesinde yeterli değildir. Özellikle hastane yönetiminin etkileşim adaletini arttıracak düzenlemeleri yapması gerekmektedir. Ayrıca yöneticiler kişilerarası davranışlarında adil olmalıdır ve iş tatminini arttırıcı iyileşmelerin yapılması vatandaşlık davranışının gerçekleşmesi için bir aracı olmaktadır.

Araştırma bazı kısıtlar altında yapılmıştır. Bunlar, sadece Kars iline özgü olması, yalnızca anketle toplanan verilere dayanması ve sadece hastaneleri kapsamasıdır. Ayrıca doğum, devlet ve araştırma hastaneleri arasında örgütsel adalet, örgütsel vatandaşlık ve iş tatmini algısı arasındaki farklılıklar dikkate alınmamıştır.

İlerleyen çalışmalara öneri olarak kişilik, kontrol odağı, özyeterlilik ve bağlılık gibi kişiye özgü ve örgüt kültürü, liderlik ve algılanan örgütsel destek gibi örgüte özgü değişkenlerin modele eklenmesi ile farklı illerde, farklı sektörlerde ve farklı veri toplama araçlarıyla çalışmaların yapılması sonuçların genellenebilmesi açısından daha sağlıkı bilgiler verebilir. Ayrıca hastanelerdeki farklı birimlerde görev yapan hemşirelerin hak ve sorumluluklarının farklı olabileceği dikkate alınarak adalet algısı, tatmin düzeyi ve vatandaşlık davranışındaki farklılıklar incelenebilir. 


\section{KAYNAKLAR}

Acker, G.M. (2004) “The Effects of Organizational Conditions on Job Satisfaction and Intention to Leave Among Social Workers in Mental Health Care” Community Mental Health Journal, 40(1): 65-73.

Adams, J.S. (1965) "Inequity in Social Exchange", Berkowitz, L (eds.) Advances in Experimental Social Psychology, New York, Academic Press.

Alexander, P. ve Ruderman, M. (1987) “The Role of Procedural and Distributive Justice in Organizational Behavior" Social Justice Research, 1: 177-198.

Arslantaş, C. ve Pekdemir, I. (2007) “Dönüşümcü Liderlik, Örgütsel Vatandaşlık Davranışı ve Örgütsel Adalet Arasındaki İlişkileri Belirlemeye Yönelik Görgül Bir Araştırma” Sosyal Bilimler Dergisi, 1: 261-286.

Baron, R. ve Kenny, D. (1986) “The ModeratorMediator Variable Distinction In Social Psychological Research: Conceptual, Strategic and Statistical Considerations" Journal of Personality and Social Psychology, 51(6): 1173-1182.

Basım, H.N. ve Şeşen, H. (2006) "Örgütsel Vatandaşlık Davranışı Ölçeği Uyarlama ve Karşılaştırma Çalışması" Ankara Üniversitesi Siyasal Bilgiler Fakültesi Dergisi, 61(4):83-102.

Basım, N., ve Şeşen, H. (2009) “Örgütsel Adalet Algıs1Örgütsel Vatandaşlık Davranışı İlişkisinde İş Tatmininin Aracılık Rolu” Osman Gazi Üniversitesi 17. Yönetim ve Organizasyon Kongresi Bildiriler Kitab1, 806-812.

Batıgün, A.D. ve Şahin, N.H. (2006) "İş Stresi ve Sağlık Psikolojisi Araştırmaları İçin İki Ölçek: A-Tipi Kişilik ve İş Doyumu” Türk Psikiyatri Dergisi, 17(1): 32-25.

Bies, R.J. ve Moag, J.F. (1986) "Interactional Justice: Communication Criteria of Fairness" Research on Negotiations in Organizations, 1: 43-55.

Brayfield, A.H., ve Rothe, H.F. (1951) "An Index of Job Satisfaction" Journal of Applied Psychology, 35:307311.

Campbell, L. ve Finch, E. (2004) "Customer Satisfaction and Organizational Justice" Facilities, 22(7/8):178-189.

Chan, M. (2000) "Organizational Justice Theories and Landmark Cases" The International Journal of Organizational Analysis, 8(1):68-88.

Colquitt, J.A., Conlon, D.E., Wesson, M.J., Porter, C.O. ve NG, K.Y. (2001) "Justice at the Millennium: A Meta-Analytic Review of 25 Years of Organizational Justice Research" Journal of Applied Psychology, 86(3): 425-445.
Cohen-Charash, Y. ve Spector, P.E. (2001) “The Role of Justice in Organizations: A Meta-Analysis" Organizational Behavior and Human Decision Processes, 86(2): 278-321.

Cremer, D.D. (2005) "Procedurel and Distributive Justice Effects Moderateed by Organizational Indentification" Journal of Managerial Psychology 20 (1): 4-13.

Cropanzano, R., Bowen, D.E. ve Gilliland, S.W. (2007) "The Management of Organizational Justice" Academy of Management Perspectives, 21(4):34-48.

Cropanzano, R., Prehar, C.A. ve Chen, P.Y. (2002) "Using Social Exchange Theory to Distinguish Procedural from Interactional Justice" Group and Organization Management, 27(3): 324-351.

Çakmak, Ö.K. (2005) "Performans Değerlendirme Sistemlerinde Örgütsel Adalet Algısı ve Bir Örnek Olay Çalışması", Yayınlanmamış Yüksek Lisans Tezi, İstanbul, İstanbul Üniversitesi Sosyal Bilimler Enstitüsü.

Çekmecelioğlu, H.G. (2005) “Örgüt İkliminin İş Tatmini ve İşten Ayrılma Niyeti Üzerindeki Etkisi: Bir Araştırma" Cumburiyet Üniversitesi Íktisadi ve İdari Bilimler Fakültesi Dergisi, 6 (2): 23-39.

Çetin, F., Basım, N. ve Karataş, M. (2011) "Çalışanların Problem Çözme Becerilerinde Örgütsel Adalet Algısı ve İş Tatmininin Rolü” Yönetim ve Ekonomi, 18(1):71-85.

Demirel, Y. ve Özçınar, M.F. (2009) "Örgütsel Vatandaşlık Davranışının İş Tatmini Üzerindeki Etkisi: Farklı Sektörlere Yönelik Bir Araştırma” Atatürk Üniversitesi İIBF Dergisi, 23(1): 129-145.

Dınç, A. ve Ceylan, A. (2008) "Kaçak Elektrik Kullanımıyla İlgili İdare Çalışanı Tutumunun Örgütsel Adalet ve İş Memnuniyeti İle İlişkisi, Çalışma Gruplarına Göre Farklılıklar" C.Ü. Íktisadi ve İdari Bilimler Dergisi, 9(2): 13-29.

Erkuş, A., Turunç, Ö. ve Yücel, R. (2011) “Örgütsel Adalet ve Örgütsel Bağlılık Arasındaki İlişkilerde İçsel ve Dışsal İş Tatmininin Aracılık Rolü: Bankacılık Sektöründe Bir Araştırma" Eskişehir Osmangazi Üniversitesi İIBF Dergisi, 6(1): 245-270.

Farh, J., Zhong, C. ve Organ, D.W. (2004) "Organizational Citizenship Behavior in The People's Republic of China” Organization Science, 15(2):241-253.

Folev, S., Kidder, D.L. ve Powell, G.N. (2002) “The Perceived Glass Ceiling and Justice Perceptions: An Investigation of Hispanic Law Associates" Journal of Management, 28(4): 471-496. 
George, J.M.. ve Jones, G.R. (1997) "Organizational Spontaneity in Context" Human Performance, 10: 153170.

Greenberg, J. ve Baron, R.A. (2000) Behavior in Organizations, 7th Edition, New Jersey, Prentice Hall.

Greenberg, J. (1990) "Organizational Justice: Yesterday, Today, and Tomorrow" Journal of Management, 16(2): 399-432.

Gürbüz, S. (2008) "İş Tatmini ve Adalet Algısının Örgütsel Vatandaşlık Davranışına Etkisi” Amme İdaresi Dergisi, 41(4): 49-77.

Gürbüz, S. (2006) “Örgütsel Vatandaşlık Davranışı İle Duygusal Bağllılı Arasındaki İlişkilerin Belirlenmesine Yönelik Bir Araştırma” Ekonomik ve Sosyal Araștırmalar Dergisi, 3(1): 48-75.

İnce, M. ve Gül, H. (2011) “The Effect of Employees' Perceptions Of Organizational Justice on OCB: An Application in Turkish Public Institutions" International Journal of Business and Management, 6(6):134-149.

İşbaşı, J.O. (2001) "Çalışanların Yöneticilerine Duydukları Güvenin ve Örgütsel Adalete İlişkin Algılamalarının Vatandaşlık Davranışının Oluşumundaki Rolü” Yönetim Araştırmaları Dergisi, 1(1):51-73.

İşcan, Ö.F. ve Sayın, U. (2010) "Örgütsel Adalet, İş Tatmini ve Örgütsel Güven Arasındaki İlişki” Atatürk Üniversitesi İktisadi ve İdari Bilimler Dergisi, 24(4): 195216.

Jahangir, N., Akbar, M. ve Begum, N. (2006) “The Role of Social Power, Procedural Justice, Organizational Commitment, and Job Satisfaction to Engerder Organizational Citizenship Behavior" ABAC Journal, 26(3): 21-36.

Konovsky, M.A. ve Organ, D.W. (1996) "Dispositional and Contextual Determinants of Organizational Citizenship Behavior" Journal of Organizational Behavior, 17: 253-266.

Kutaniş, R.Ö. ve Mesci, M. (2010) “Örgütsel Adaletin Çalışanların İş Tatminine Etkisi: Turizm Alanında Eğitim Veren Bir Yükseköğretim Kurumuna Yönelik Bir Örnek Olay Çalışması" Selçuk Üniversitesi İIBF Sosyal ve Ekonomik Araşttrmalar Dergisi, 527-552.

Lambert, E.G., Hogan, N.L. ve Griffin, M.L. (2007) "The Impact Of Distributive and Procedural Justice on Correctional Staff Job Stress, Job Satisfaction, and Organizatioal Commitment" Journal of Criminal Justice, 35: 644-656.

Lee, K. ve Allen, N. (2002) "Organizational Citizenship Behavior and Workplace Deviance:The Role Of Affect And Cognitions"Journal of Applied Psychology,87: 131-142.
Li, N., Crant, J.M. ve Liang, J. (2010) "The Role of Proactive Personality in Job Satisfaction and Organizational Citizenship Behavior: A Relational Perspective" Journal of Applied Psychology, 95(2): 395404.

Liao, W. ve Wei-Tao, T. (2006) "Organizational Justice, Motivation to Learn, and Training Outcomes" Social Behavior and Personality, 34 (5): 545-556.

Lowe, R.H. ve Vodanovich, J. (1995) "A Field Study of Distributive and Procedural Justice As Predictors of Satisfaction and Organizational Commitment" Journal of Business and Psychology, 10: 99-114.

Luthans, F. (1995) Organizational Behavior, 7th Edition, New York, McGraw-Hill.

Martin, C.L., ve Bennett, N. (1996) "The Role Of Justice Judgments İn Explaining The Relationship Between Job Satisfaction And Organizational Commitment" Group \& Organization Management, 21(1):84-104.

Mcfarlin, D.B. ve Sweeney, P.D. (1992) "Distributive And Procedural Justice as Predictors of Satisfaction With Personal And Organizational Outcomes" Academy of Management Journal, 35(3): 626-637.

Meydan, C.H. ve Şeşen, H. (2011) Yapısal Eşitlik Modellemesi AMOS Uygulamalar, Ankara, Detay.

Mert, İ.S. (2010) "İş Tatmininin Alt Boyutlarının Örgütsel Vatandaşlık Davranışı Üzerindeki Etkisi: Yöneticiler Üzerine Bir Araştırma” KHO Savunma Bilimleri Dergisi, 9(2): 117-143.

Moorman, H. (1991) "Relationship Between Organizational Justice and Organizational Citizenship Behaviors: Do Fairness Perceptions İnfluence Employee Citizenship?" Journal of Applied Psychology, 76:845-855.

Moorman, R.H. ve Blakely, G.L. (1995) "Individualism-Collectivism as an Individual Difference Predictor of Organizational Citizenship Behavior" Journal of Organizational Behavior, 16:127-142.

Nunnaly, J.C. (1978) Psychometric Theory, New York, McGraw-Hill.

Olkonen, M.E. ve Lipponen, J. (2006) "Relationship Between Organizational Justice, İdentification With Organization and Work Unit, And Group-Related Outcoes" Organizational Behavior and Human Decision Processes, 100:202-215.

Organ, D.W. (1997) "Organizational Citizenship Behavior: Its Construct Clean-Up Time" Human Performance, 10(2): 85-97.

Organ, D.W. (1990) "The Motivational Basis of Organizational Citizenship Behavior" Research in Organizational Behavior, 12:43-72. 
Organ, D.W. (1988) "A Restatement of the Satisfaction-Performance Hypothesis" Journal of Management, 14: 547-557.

Özer, G. ve Günlük, M. (2010) “Örgütsel Adaletin Muhasebecilerin İş Memnuniyeti ve İşten Ayrılma Eğilimine Etkisi” Gaziantep Üniversitesi Sosyal Bilimler Dergisi, 9(2): 459-485.

Podsakoff, P.M., Mackenzie, S.B., Paine J.B. ve Bachrach, D.G. (2000) "Organizational Citizenship Behaviors: A Critical Review of the Theoritical and Empirical Literature and Suggestions for Future Research" Journal of Management, 26(3): 513-563.

Podsakoff,P.M. veMacKenzie, S.B.(1994) "Organizational Citizenship Behaviors And Sales Unit Effectiveness" Journal of Marketing Research, August, 351-363.

Polat, S. ve Celep, C. (2008) "Ortaöğretim Öğretmenlerinin Örgütsel Adalet, Örgütsel Güven, Örgütsel Vatandaşlık Davranışlarına İlişkin Algıları” Kuram ve Uygulamada Eğitim Yönetimi, 54:307-331.

Quersteın, V., McAffe, R.B. ve Glassman, M. (1992) "The Situational Occurences Theory of Job Satisfaction" Human Relations, 45(8): 859-873.

Ramamoorthy, N. ve Flood, P.C. (2004) "Gender and Employee Attitudes: The Role of Organizational Justice Perceptions” British Journal of Management, 15: 247-258.

Robbins, S. ve Judge, T.A. (2007) Organizational Behavior, 12.Edition, New Jersey, Prentice-Hall.

Samad, S. (2006) "Predicting Turnover Intentions: The Case of Malaysian Government Doctors" The Journal of American Academy of Business, 8(2): 113-119.

Saruhan, Ş.C. ve Özdemirci, A. (2011) Bilim, Felsefe ve Metodoloji, İstanbul, Alkım.

Smith, C.A., Organ D. ve Near, Y. (1983) "Organizational Citizenship Behavior: Its Nature and Antecedents” Journal of Applied Psychology, 68(4): 653-663.

Solmuş, T. (2004) İ̧ Yaşamında Duygular ve Kişilerarası İlişkiler, İstanbul, Beta.

Sounders, N., Mark, K. ve Thornhill, A. (2003) "Organizational Justice, Trust and the Management of Change an Exploration" Personel Review, 32 (3): 360-375.

Şeşen, H. (2010a) "Kontrol Odağı, Genel Öz Yeterlik, İş Tatmini Ve Örgütsel Adalet Algısının Örgütsel Vatandaşlık Davranışına Etkisi: Ankara’da Bulunan Kamu Kurumlarında Bir Araştırma” Hacettepe Üni. İktisadi ve İdari Bilimler Fakültesi Dergisi, 28(2): 195-220.

Şeşen, H. (2010b) "Adalet Algısının Tükenmişliğe Etkisi: İş Tatmininin Aracı Değiş̧en Rolünün Yapısal Eşitlik Modeli İle Testi” Savunma Bilimleri Dergisi, 9(2): 67-90.
Tansky, J.W. (1993) "Justice and Organizational Citizenship Behavior: What Is the Relationship?" Employee Responsibilities and Rights Journal, 6(3): 195207.

Taştan, M ve Yılmaz, K. (2008) "Organizational Citizenship and Organizational Justice Scales' Adaptation to Turkish" Eğitim ve Bilim, 33(150): 87-96.

Toker, B. (2007) "Demografik Değişkenlerin İş Tatminine Etkileri: İzmir'deki Beş ve Dört Yıldızlı Otellere Yönelik Bir Uygulama” Doğuş Üniversitesi Dergisi, 8 (1): 92-107.

Ugboro, I. ve Obeng, K. (2000) “Top Management Leadership, Employee Empowerment, Job Satisfaction, And Customer Satisfaction In Total Quality Management Organizations: An Empirical Study" Journal Of Quality Management, 5(2): 247-272.

Verhoef, P.C. (2003) "Understanding the Effect of Customer Relationship Management Efforts on Customer Retention and Customer Share Development" Journal of Marketing, 67: 30-45.

Wasti, S.A. (2001) "Örgütsel Adalet Kavramı ve Tercüme Bir Ölçeğin Türkçe'de Güvenilirlik ve Geçerlilik Analizi”, Yönetim Araştırmaları Dergisi, 1 (1): 1-30.

Williamson, K. ve Williams, J. (2011) “Organisational Justice, Trust and Perceptions Fairness in the Implementation of Agenda for Change" Radiography 17: 61-66.

Williams, L.J. ve Anderson, S.E. (1991) "Job Satisfaction and Organizational Commitments as Prectors Organizational Citizenship and In-role Behavior" Journal of Management, 17: 601-617.

Yelboğa, A. (2012) "Örgütsel Adalet ile İş Doyumu İlişkisi: Ampirik Bir Çalışma” Ege Akademik Bakış, 12 (2): 171-182.

Yıldırım, F. (2007) "İş Doyumu Ve Örgütsel Adalet İlişkisi” Ankara Üniversitesi SBF Dergisi, 62 (1): 253-278.

Yoon, J. (1996) "Fairness Issues and Job Satisfaction Among Korean Employees: The Significance of Status Value and Procedural Justice in Work Orientation" Social Justice Research, 9(2): 121-143.

Yürür, S. ve Keser, A. (2010) "İşe Bağlı Gerginlik İle İş Tatmini İlişkisinde Duygusal Tükenmenin Aracı Rolü” Ankara Üniversitesi SBF Dergisi, 65 (4): 165-194.

Yürür, Ş. (2008) "Örgütsel Adalet ile İş Tatmini ve Çalışanların Bireysel Özellikleri Arasındaki İlişkilerin Analizine Yönelik Bir Araştırma” Süleyman Demirel Üniversitesi, I.I.I.B.F. Dergisi, 13(2): 295-312. 